\title{
Comment:
}

\section{On Terms: Russians Are Soviets, But Soviets Aren't Always Russians}

\author{
Richard W. Couch ${ }^{1}$ \& Brenda Kay Weddle ${ }^{2}$ \\ University of Kansas
}

Behaviorists for Social Action (BFSA) Journal serves as a forum for scholarly discussion of issues regarding the role of behavior analysis as an approach to combating social injustice. Necessarily then, political ideologies are topics of articles published in the Journal (e.g., Ulman, 1953). And, more often than not, these articles refer to particular countries. To date, well over a dozen countries have been mentioned. One country whose name inevitably arises is the Union of Soviet Socialist Republics (USSR), or more commonly, the Soviet Union. The Soviet Union has been discussed a few times (Morrow, 1979; Nevin, 1954; Ulman, 1979) as either the Soviet Union or the USSR. On rare occasions (Nevin, 1954; Skinner, 1979) the USSR has been referred to as Russia. However, a brief review of Soviet history will illustrate that this usage is incorrect.

In late 1922, following the Bolshevik revolution of 1917, the Union of Soviet Socialist Republics was formed from the former Russian Empire. Today the USSR is composed of fifteen Soviet Socialist Republics, of which the Russian Soviet Federated Socialist Republic is but one. Besides Russians and the Russian language, within the Soviet Union coexist 121 major nationalities and 113 languages. While it is true that the government capitol of the USSR is in Russia, in Moscow, it is not true that all Soviet leaders are Russian. Josef Stalin, perhaps the most well known Soviet leader, was not Russian, but Georgian, being from the Republic of Georgia and having the Georgian language as his native tongue.
The terms "Russian", "Ukranian", "Georgian", etc., are not just geographic terms as are Kansan, Texan, or Californian, but denote nationalities as in Irish-American or Hispanic. Ethnic pride is strongly reinforced among Soviet peoples, and national cultures, languages, and traditions are rigorously maintained (despite the Communist theory of a "nationless state"). Although a colloquial expression, in more than one Soviet republic a great injury would be done to refer to a native of that republic as Russian.

Referring to the USSR as Russia is, therefore, somewhat analogous to referring to the United States of America as California. While this distinction may seem trivial to some, we feel it is worthwhile to prompt socially concerned behavioral researchers and practitioners to be aware of their language; an international organization such as BFSA has this responsibility.

\section{References}

Morrow, J. E. (interviewer) (1979). BFSA interviews B. F. Skinner. Behaviorists for Social Action Journal, 2, 1.

Nevin, J. A. (1953). Old dogs and new tricks: Disarmament and alternatives to war. Behaviorists for Social Action Journal, 4, 2.

Skinner, B. F. (1979). BFSA interviews B. F. Skinner. Behaviorists for Social Action Journal, 2, 1.

Ulman, J. (1979). A critique of "Skinnerism: Materialism minus the dialectic." Behaviorists for Social Action Journal, 1, 2. 